\title{
Revitalizing Millennial Spirituality within Social Media at the Hijrah Shift Youth Community in Bandung City
}

\author{
Faizal Arifin ${ }^{1 *}$ \\ ${ }^{1}$ Syarif Hidayatullah State Islamic University, \\ Jakarta, Indonesia
}

Article Information

Submitted April 23, 2021

Revised August 04, 2021

Accepted August 16, 2021

Published April 01, 2022

\begin{abstract}
Simple access to social media within internet networks is a new phenomenon that has become a major social need during the 4.0 Industrial Revolution. Pemuda Hijrah Community invites the millennial generation to explore Islam through communication messages towards a positive change in attitude by utilizing social media. The research aims to examine the use of social media by the Pemuda Hijrah Community (Shift) in conveying Islamic values to the millennial generation. This research uses the theory of Social Media Marketing and Cyber Public Relations through the netnographic method. The results show that the Pemuda Hijrah Community utilizes social media as a means of preaching, spiritual education, sharing information and activities, and changing the stigma of Islam as orthodox teaching for the older generation, into pop-culture teachings relevant to Millennials. The Pemuda Hijrah Community utilizes social media marketing to create a spiritual revitalization of the millennial lifestyle with Islamic character, thereby strengthening its identity as a religious millennial Muslim in Indonesia.
\end{abstract}

Keywords: Millennial; Hijrah Youth Community; Revitalization of Spirituality; Social media; Character Building.

\section{Introduction}

The ease of accessibility of social media delivered a new phenomenon in a society where the internet is a significant need in the era of Industrial Revolution 4.0. This phenomenon mainly transpires in big cities, which have already been facilitated by the internet network, both public and individual access. The implication of this phenomenon is the change of digital era communication style which most people have a gadget with a social media account such as Instagram, Facebook, Twitter, or similar platform (Mulawarman \& Nurfitri, 2017). Internet use, based on data from the Central Statistics Agency (BPS), is dominated by the use of social media, while active internet users are primarily millennials (Susanti, 2020). This millennial generation is certainly a potential target for da'wah programs to revitalize Islamic values.

In the context of the development of da'wah in Indonesia, social media technology is a new phenomenon. Expression of religiosity develops in the public sphere driven by internet technology. This phenomenon contradicts what modernization theorists predict regarding secularization and modern public life, which is considered to

\footnotetext{
*Author Correspondence: Faizal Arifin, email: faizalarifin@stiabiru.ac.id

Copyright (C) 2022 Faizal Arifin
} 
have missed the presence of religion (Slama \& Barendregt, 2018, pp. 1-3). A review of the phases of da'wah's development in Indonesia is necessary to understand the changes and developments of da'wah

A historical review shows that postindependence, da'wah in academia began with the government's formal recognition of the academic status of da'wah discourse with the establishment of Da'wah departments since 1950 at various PTAIN (Hasnawirda, 2012, p. 166). Academic activism until the 1960s became the root of the intellectual process in the next decade, which the Islamic Ulema Council (MUI) then played a role in da'wah in the 1980s (Hasnawirda, 2012). The da'wah curriculum was implemented in the 1990s at PTKIN so that da'wah studies were growing, studying new da'wah with the explosion of da'wah books in Indonesia (Hasnawirda, 2012).

The new challenge of da'wah in the industrial revolution 4.0 era causes optimization of social media necessary. Wai Weng (2018) stated his research on Felix Siuaw's da'wah, showing that social media platforms make it possible to spread Islamic messages that are packaged creatively or attractively through various circulations of text and images and videos to attract public attention (Weng, 2008). 2015, pp. 75-77). Dominik Muller (in Wai Weng, 2015) mentions 'Pop Islamism' (pop Islamism) to understand how Muslim youths use pop culture to promote the Islamic agenda. In this context, research on the Pemuda Hijrah is one of the phenomena of 'Pop Islamism', which is shown through the representation of posting da'wah messages on Instagram.

Indonesia is one of the countries with the most social media users. Statistia, a world statistics site, notes that Indonesia is in the top five, with the highest number of Instagram accounts, with around 78 million users (Statistia, 2020). This number is dominated by the younger generation, including the millennial generation. It was recorded that in April 2020, the number of Instagram users reached 66 million people, more than a third of which 45 million were users in the age range of 18 to 34 years, while the other 24 million users had an age range between 18 to 24 years (Abbas, 2020). Based on 2018 BPS data, internet use is intended for entertainment functions (45.07\%), education (25.87\%), sending or receiving email (21.1\%), e-commerce (10.82\%), financial facilities (5.08\%), and others (12.84\%) (Susanti, 2020). The internet also provides spiritual education, especially to the millennial generation, currently dominating the global flow of information. In addition to various positive impacts, globalization can be a challenge for religion because it allows threats to Islamic identity, mindset and values.

The dominance of the millennial generation and the reasonably extensive use of the internet in Indonesia are challenges for various types of community groups. The community must adapt to technological developments, while the organization's activities, programs, needs, and goals must continue to run. Not only adapting, communities previously limited in spaces for offline social activities now use social media to touch and market ideas, promote, and fulfil organizational needs.

Several studies show the urgency of using social media by communities or organizations. Angela and Yoedtadi show the results of the research that the history lover community, the Indonesian Historia Community (KHI), 
utilizes social media in order to reach the younger generation while carrying out organizational goals, namely the functions of information sources, recruitment, education, interaction and communication facilities, and creating differentiation (Angela \& Yoedtadi, 2019).

In addition to helping organizational functions, social media can also trigger an action or movement that reveal the identity of the community. Research on the social media of the Yogyakarta Youth Community by Ramma Wisnu Dewantara and Derajad S. Widhyharto from the University of Indonesia shows that new space in social media can trigger the emergence of a social movement (Dewantara \& Widhyharto, 2016). Social media has succeeded in disseminating topics and information not only to provoke movement, but also to create a support from community members for specific issues and interests.

In religious life and activities, the Pemuda Hijrah (Shift) community uses social media to revitalize Islamic spirituality for the millennial generation. Pemuda Hijrah is different from other Muslim organizations or communities in "da'wah"; they introduce a new Islamic lifestyle for millennials through popular culture (pop culture). Pemuda Hijrah Community captured the opportunity to introduce an Islamic lifestyle by optimizing the use and utilization of social media such as Instagram, Facebook, Twitter, and Youtube.

Social Media Marketing is a trend that has persisted for the last five years. In the current marketing world, $75 \%$ of consumer decisions in shopping are influenced by social media marketing (Anderson, 2019). The use of social media for non-profit organizations such as Pemuda Hijrah through social media marketing techniques deliver propaganda, thoughts, and the identity of the Pemuda Hijrah to be closer to many people without spending a lot of power and effort. As mentioned by Anderson (2019), optimizing the use of social media marketing can "bring you closer to thousands of people without much effort" (Anderson, 2019).

Pemuda Hijrah is a community built from the marketing effectiveness of social media. According to Alex Inkeles, the essence of the community is a sense of common bond, shared identity, membership in a group that adheres to several physical or spiritual aspects, with mutual respect, coupled with the recognition of rights and obligations refer to all of the values identified. (Inkeles, 1964). The identity of Pemuda Hijrah who started from the community began to penetrate the individual as its members so that in this context, the phenomenon of spirituality revitalization emerged, which was interesting to study.

Based on the above explanation, this study seeks to discuss how Pemuda Hijrah uses social media in terms of efforts to revitalize the spirituality of millennials.

\section{Method}

The approach used in this qualitative research is the Netnographic method, which analyzes aspects of digital content, with posting of Pemuda Hijrah's da'wah content on social media as the primary data source.

The main data source is the primary reference for analyzing the all-digital da'wah phenomenon in the Industrial Revolution 4.0. The netnographic method is part of an ethnographic study specializing in culture and online communities (Bakry, 2017, p. 21). In this context, researchers conduct online 
field research to collect data and understand the culture of the community (Bakry, 2017), in this context, the "Youth Hijrah" Community.

Data processing is carried out by operationalizing the theory of Social Media Marketing, which is related to the function of social media, which is descriptive-analytically expected to describe, record, analyze and interpret in revealing facts related to social media by "Youth Hijrah" (Shift). In the operational context, the researcher limits the analysis aspect of the "Youth Hijrah" Instagram function to discussions related to the educational function, the function of information sources, and the function of creating differentiation. Through these aspects, it is hoped to provide an overview of how the Pemuda Hijrah Instagram account uses creative popular culture to attract audiences or da'wah targets in revitalizing Islamic values.

\section{Result}

Pemuda Hijrah is a community that was founded in 2015, consisting of various youth associations in Bandung (Affandi \& Octavianti, 2019). Among the founders were the skateboard community, Indie musicians, and members of motorcycle gangs who were united by one thing in common, namely the pledge to emigrate to improve themselves towards strengthening Islamic teachings. Young hijrah then continued to develop and progress so that more and more other communities from various orientations joined themselves, including activists, da'wah activists and young academics.

The most popular figure from the Pemuda Hijrah (Shift) movement is Ustadz Hanan Attaki. Hanan Attaki belongs to the millennial generation born in 1981. He is an alumnus of Al-Azhar Egypt, who has a role in the public sphere and has legality as a new religious authority in Egypt. Indonesia, such as Tuan Guru Bajang and Ustadz Abdul Somad. The fundamental difference between Hanan Attaki and "celebrity clerics" is Hanan Attaki's concern for the preaching of the study of urban youth (Rofiqoh, 2019, pp. 109-110).

Hanan Attaki formed the Hijrah Youth (Shift) using the contemporary model of the millennial style in his da'wah approach (Dilawati, Darmawan, Hernawan, Waluyojati, \& Darmalaksana, 2020, p. 59). Hanan Attaki, through "Shift", shows that studying Islam is fun, not rigid and not scary (Dilawati et al., 2020). Da'wah innovation was also initiated by Hanan Attaki, for example, through a minor waste program that seeks to integrate da'wah with environmental issues and change the style of youth who previously only hung out in cafes into hanging out in mosques as well (Nizar, 2020). Hannan Attaki appears to carry the appearance of young people by adapting to his target audience, who has a segmentation of teenagers and young people who are active in social media as a medium of da'wah (Arnus, 2018, p. 175).

Hanan Attaki is a figure who plays a significant role in developing Pemuda Hijrah in various cities in Indonesia, which is supported by many factors. Dian Dwi Jayanto's study (2020) states that the success of the Pemuda Hijrah movement is not only determined by the power of the preachers or aspects of social media marketing management. However, it is also a deliberative effort that unites various cultural elements in the entities of Muslim youth in Bandung, consisting of musicians, street football players, bicycle enthusiasts, and other communities integrated into 
religious identity (Jayanto, 2020, pp. 110-111 ). A harmony integrates the hobbies of Muslim youth in Bandung with a religious dimension, which shows that crossing identities between lifestyle or modernity can be following Islamic values through Pemuda Hijrah (Jayanto, 2020).

Pemuda Hijrah has another name, namely "Shift". "Shift" comes from Old English "sciftan" and German "schichten". According to the Cambridge Advanced Learner's Dictionary, "shift" has several meanings, including moving, changing, being different from before (become different). These meanings show the same essence, namely changing and moving for the better than before: "hijrah". Meanwhile, Concise English Dictionary defines "shift", which is a quality change, an action to move from one place to another. The choice of the term "shift" is exciting because, in addition to matching the definition of the word referring to "hijrah", change, displacement, the term "shift" is also attached to the shadow of the keys on the keyboard of both gadgets and laptops. Therefore, in addition to branding with the impression of technological and digital progress, the "shift" key can change lowercase letters to uppercase letters so that it has a philosophical meaning for every youth to be able to change themselves from something small to have great potential to achieve wellness value in religion.

Pemuda Hijrah has a tagline that represents the identity of its community, namely "Banyak Maen, Banyak Manfaat (Many Plays, Many Benefits)" with an additional explanation, "Let us learn together while playing, the more we learn, the more flexible we will be in socializing" (pemudahijrah.id, 2020). Compared to using a tagline that raises religious orthodoxy, Pemuda Hijrah prefers a tagline that matches the branding of the millennial generation, mainly hanging out, playing, but still delivering benefits.

As shown in pigure 1, Pemuda Hijrah has several social media account platforms. Based on information from the official website, Pemuda Hijrah includes an Instagram account shiftmedia.id with 1.9 million followers, 143,698 Facebook Fanpage members, Youtube with 470,000 subscribers, and 64.700 followers on Twitter. Through various social media platform accounts, Pemuda Hijrah publishes various activities and information and shows the identity of their community. After describing the analysis of data from different social media account platforms, the researcher will discuss the findings related to the communication messages conveyed, especially those oriented and related to aspects of spirituality revitalization for the millennial generation.

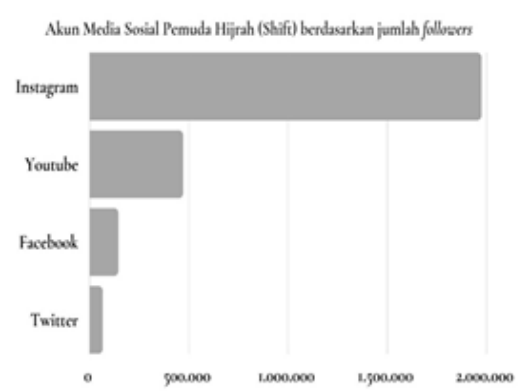

Figure 1. The Number of Pemuda Hijrah (Shift)'s Followers from Various Platforms

The official Instagram account Pemuda Hijrah is called shiftmedia.id. This account has the most followers compared to followers on other platforms. Based on data compiled by socialblade.com, showing the latest data as of 26 November 2020, the number of shiftmedia. id uploads reached 668 photo and video posts (Pemuda Hijrah's Instagram Stats Summary Profile (Social Blade Instagram Statistics)," n.d.). Still using the identical data analysis 
source, in terms of follower activity, the average likes reached 15,185 people for each post, and the average response was 66.85 comments. This number shows that there are intensive virtual interactions through Pemuda Hijrah social media accounts and various virtual dialogues that are enough to bring followers closer to the Pemuda Hijrah movement. The study conducted in this article is not an in-depth statistical analysis, but information about followers is sufficient to provide an overview of the virality of the

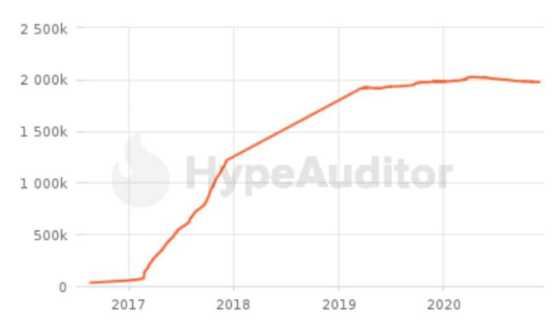

"Shift" account.

Figure 2. Graph of shiftmedia.id followers

The graph in Figure 2 above is a data analysis carried out by a hypeautditor. The image shows that the development of shiftmedia.id accounts prior to 2017 had an insignificant number of followers ("Youth Hijrah - HypeAuditor report for Instagram account shiftmedia.id | HypeAuditor Youtube, TikTok \& Instagram AI analytics," 2020). Starting in mid-2017, the shiftmedia.id account began to experience a significant increase so that in 2018 it reached 1,250,000 followers. Whereas in 2019, it reached 1,700,000 followers, and throughout 2020 it almost reached 2 million followers. The increase in the number of followers shows that Pemuda Hijrah is embracing more and more millennials. Based on this significant amount, the researcher limits the research to the Instagram platform belonging to Pemuda
Hijrah (Shift). In addition to the number of followers, various offline events carried out by Pemuda Hijrah were attended by many young people, even worshipers at night prayers filled public roads around the Al-Lathif mosque.

\section{Discussion}

\section{Instagram Content of shiftmedia.id}

a. Education

One of the functions of education, especially spiritual education, is da'wah. The education used by Instagram shiftmedia.id includes short videos duration 30 seconds to 1 minute. Educational videos are dominated mainly by lectures or studies by multipleclerics who are the sources of the study. The snippet of the lecture provides recommendations for listening to the full study lecture through the Youtube channel. The various messages conveyed are oriented towards revitalising spirituality, namely, restoring and bringing back Islamic values to the millennial generation through contemporary styles.

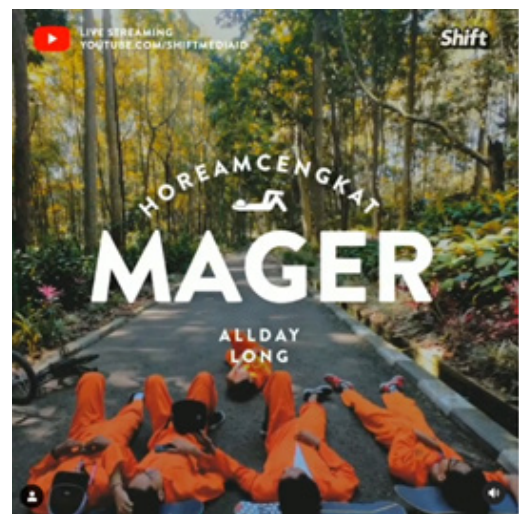

Figure 3. The "Mager" video educational poster contains an invitation not to be counterproductive

The video title is short and raises curiosity about the millennial language to attract the young generation. As shown in figure 3 and figure 4, among the short and 
slang titles are "Mager", "Ge'er", "Rejected", "Woles", "The Energy", " Gagal Paham (Failure to Understand)", "Eh! Ko Gitu", "Modus", "Waktu Lagi Butuh", "Modal Hidup", "Bangkrut", "Diam", "Ujian", and other short titles. In addition to video clips of lectures with short titles, there are also videos with titles that immediately show the substance, including "Doain Orang Yang Ngeselin", "Efek Dosa Dalam Kehidupan Kita", "Cinta Berbuah Surga", " Sederhana tapi Istimewa", "Ngebet Ta'lim", "Miracle of Istigfar", "Manusia Paling Sibuk di Akhirat", and so on.

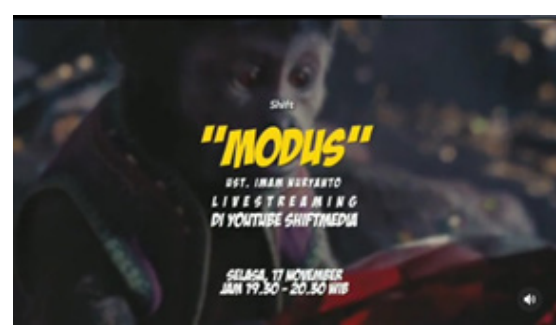

Figure 4. An educational snippet of "Modus" is an invitation to study with the theme of straightening intentions.

Education on the shiftmedia.id Instagram account is also published in the form of film recommendations. Recommended films are films that are considered to have specific moral messages or values following the identity of the Pemuda Hijrah. The films presented are not only entertainment but also have educational value regardless of genre.

Among the films that have the essence of hijrah is the recommendation for the film "Kiamat Sudah Dekat", which tells the story of a young man who begins to learn religion with various twists and turns to become a better human being. The recommended film with Islamic values is "Negeri 5 Menara", which tells the story of five students in a boarding school with many values of friendship, struggle, dreams, and education. The film "Tozkoparan" is recommended because it shows a small child with lung disease, loaded with faith values. The French film "Le Grand Voyage" was posted because it contains the story of a French-Moroccan teenager who is forced to accompany his father to go on Hajj by car from France to Saudi Arabia.

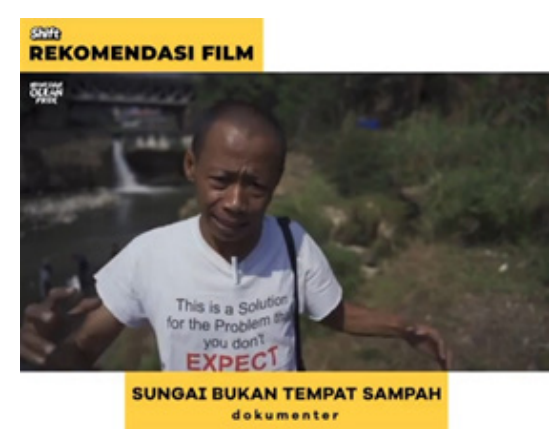

Figure 5. Recommendations for environmentalthemed films for Pemuda Hijrah

Apart from being dominated by films with hijrah and Islamic values, film recommendations also contain non-spiritual messages. For example, Ocean Pride's "Sungai Bukan Tempat Sampah" as shown in figure 5, documentary film raises environmental issues. The film displays the values of protecting the environment, reducing plastic, prohibiting littering with effort on the expectations of being posted, namely, "to sorting out waste, composting organic waste in households, and similar theme." Other themes include a documentary film, "The Great Hack", which has an educational message so that followers respond wisely to social media and various other networking platforms.

\section{b. Information Sources}

Instagram has a function for communities and organizations as a source of information for each activity. Various activities published by shiftmedia.id on the Instagram account contain invitations or plans, organizing events, and activity documentation reports published in excellent cinematography or 
creative ideas.

Publication of activities contains a religious studies schedule designed creatively packaged without missing the essence. For example, Pemuda Hijrah's Instagram account gives the tagline "ngabuburide" to refer to "ngabuburit", followed by breaking the fast together. Weekend studies are called "Shift Weekend", or night studies are called "Sharing Nights." The Saturday night study, usually arranged by young people for activities outside of religion to attract millennials, is entitled "Saturday Night Study (Satnight)." Other religious studies that are promoted are information on religious study activities that move or change places, for example, "Go Shift to Sabuga", "Go Shift Garut \& Tasik", "Go Shift Pusdai", "Go Shift Karawang", "Go Shift Soreang", "Ngabuburide Makassar", or other areas.

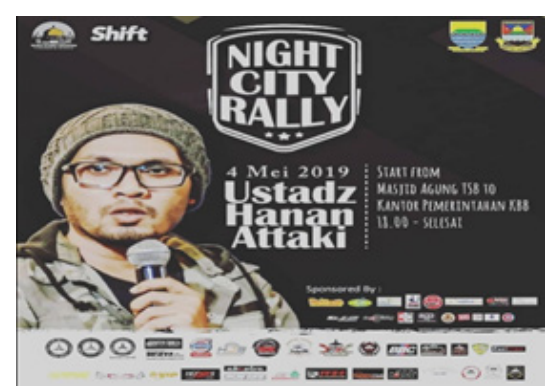

Figure 5. Publication Poster of the Automotive Community Religious Study

Pemuda Hijrah provided information on the theme of the study within informal and millennial ways. Figure 5 shows a joint religious study with the Automotive Community with the tagline "Night City Rally." Other labelling includes the activity's title "Hunting Night Treasure" to promote a theme of afternoon religious study activities at the mosque. The tagline "Influence of World History" was given on a weeknight study activity that contains inspiration from famous and successful people in the world, followed by Qiyamul Lail.

Figure 5 also shows how the phenomenon of young preachers, including Ustadz Hanan Attaki, enlivened the knowledge assembly through a different appearance like preachers in general. The Ustadz is depicted wearing an army jacket and a beanie head covering instead of a cap like the usual preacher. Like the research conducted by Fatoni and Rais (2018) on young preachers, Ust. Handy Bonny shows that young people willingly accept this casual impression. The delivery of da'wah uses polite, relaxed, not patronizing language, uses light language but still cannot be separated from maintaining ethics and politeness (Fatoni \& Rais, 2018). In this context, Ustadz Handy Bonny also became one of the resource persons in the activities carried out by the Pemuda Hijrah study.

To inform the study activities, the Pemuda Hijrah also carried out bizarre ways. Through a creative and unique way, it is hoped that it will develop the branding of young people as da'wah targets who are pleased with imaginative new things. Even Katz, Gurevitch, and Haas mention that one of the five human needs related to media is the need for imagination because it is considered capable of releasing tension and entertaining (Prihatiningsih, 2017, p. 53).

The delivery of information through unique and creative packaging in Pemuda Hijrah, for example, is through word guessing, which has also been included where there are images of barrels, combs, and fish, and is guessed by followers with the answer, "Tong Sisirikan" or the message, do not be jealous. The study on the invitation to give love to parents is entitled "Supermom", as shown in Figure 6. 


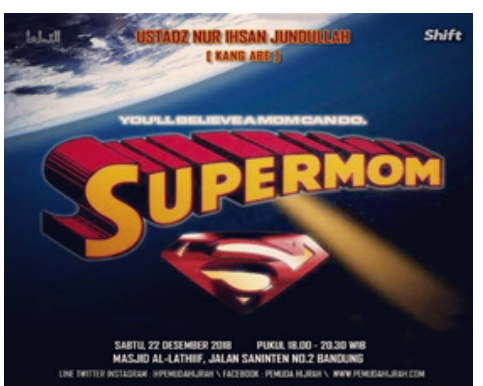

Figure 6. Poster for the Study with the Themed of Parents' Love.

In addition to religious activities, social media is used by Pemuda Hijrah to publish webinars or talk shows. An example is an invitation to participate in an online webinar with the theme of environmental issues in collaboration with PD. Kebersihan and Zero Waste Adventure community. The Pemuda Hijrah typically packages these various information publications by creative and unique displays and designs.

\section{c. Creating Differentiation}

Pemuda Hijrah creates differentiation to increase the branding of the community messages try to deliver. Pemuda Hijrah creates a trend by making the millennial religious generation not orthodox, formal, or traditional. Therefore, Pemuda Hijrah presents a millennial figure who remains stylish without violating or ignoring religious rules. The mission can be perceived from a video documentary about reading the Quran with the background of Qiyamul Lail activities attended by thousands of youths as seen on Figure 7.

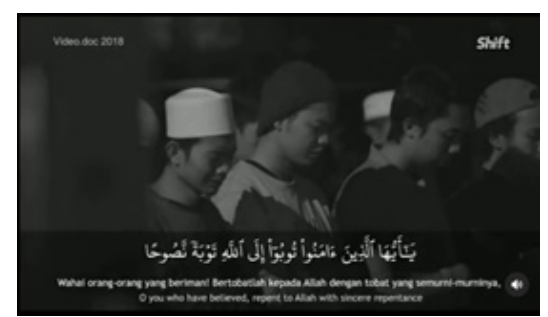

Figure 7. Video of the Quran Verse with the Background of the Qiyamul Lail activity
Figure 7 not only shows a snippet of an Imam reading the Qur'an at the Pemuda Hijrah activity. However, it shows the diversity of the Pemuda Hijrah, who are united in the momentum of spirituality, specifically the night prayer. It is perceived that the youths have different appearance symbols, each wearing a white cap, skullcap, not wearing a cap, and even wearing a hat. In addition, the clothes worn are also various, particularly Muslim clothes, t-shirts, and collared shirts. This difference represents a symbol of differentiation from Pemuda Hijrah that Millenials do not have to have the same physical or appearance, but spiritual values are a more critical essence.

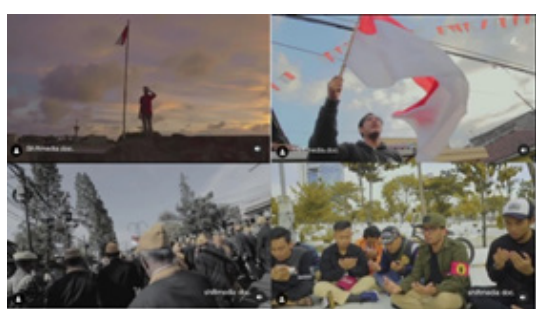

Figure 8. Some Documentary Videos Themed of Indonesia and Pemuda Hijrah

Other exciting publications in creating differentiation eliminate the negative stigma associated with Pemuda Hijrah, as shown in Figure 8. For example, the impression of radicalism and intolerance that some groups frequently correlate with the hijrah trend. Other studies even conclude that the phenomenon of the hijrah movement has missed its substantive meaning and is "only symbolic" (Addini, 2019). Therefore, research on the social media of Pemuda Hijrah shows that the substance of Islamic values remains essential. Within their Instagram account, Pemuda Hijrah shows the identity of their affection for Indonesia through posting prayers for the country of Indonesia, celebrating the anniversary of the Republic of Indonesia, commemorating Hero's Day at the 
Hero's Cemetery, as well as documentaries commemorating the youth oath, as well as other activities with the theme of love for the country.

\section{Spiritual Revitalization via Instagram}

Instagram is a proper medium to market community ideas to the public, especially the millennial generation. Research conducted by Shaohai Jiang and Annabel Ngien on 388 respondents shows that Instagram can reinforce the positive effects of social media among the young population, such as helping educators and positive campaign programs (Jiang \& Ngien, 2020). The number of followers of Pemuda Hijrah continues to increase to almost 2 million people as an implication of the applied social media marketing techniques. Research conducted by Nurasiah Ismail et al. (2017) shows that it is essential for da'wah messages to be presented in an attractive and well-packaged style to reach the da'wah target (Nurasiah Ismail, Abidin, \& Fatoni, 2017).

With the potential quantity of followers and activists both on social media and at the Al-Lathif mosque, Pemuda Hijrah can accommodate hegemony to invite young people to campaign for a movement to strengthen religious values through positive campaigns. Various activities carried out by the Pemuda Hijrah, such as Campaign and Special Events -as described in the pictures in the previous discussion- are essential in developing the organization. Turhamun noted that in managing and developing community organizations, fundraising is needed, which is not solely material but also non-material assistance so that it requires an accurate communication strategy (Turhamun, 2020).
In this context, the invitation and campaign carried out by Pemuda Hijrah is quite effective in mobilizing youth and their followers to participate by optimizing communication through Instagram. This achievement can be noticed in the number of young people who attend religious study activities and social or worship activities.

Through social comparison analysis (social comparison), posting photos or videos from shiftmedia.id can hold implications for the process of influencing each other in social interactions where followers compare themselves with other people who have "emigrated" or are active having an increased intensity in formal religious activities (worship) or study activity (education). The sense of comparing oneself with others will carry out positive activities upward, triggering a person to gain self-improvement (Lianawati, 2011).

The use of Instagram by Pemuda Hijrah can also meet the needs of personal and social integration for young people. Based on Witanti Prihatiningsih's research, two of the five motives for using Instagram are to fulfil personal integration where the individual's status is trying to be strengthened, credible, have trust and stability, which can be fostered through Pemuda Hijrah religious studies. In addition, the need for social integration can be met through various group activities and joining with others through various activities, both da'wah/worship and social activities, such as hanging out, which is still valid.

The actualization of the teachings of revelation to the millennial generation is not immediately arranged through education or da'wah that revitalizes spirituality. Pemuda Hijrah, through popular culture, is not free from criticism from both traditionalist and 
liberal groups. In contrast to several groups who hurled accusations and criticisms harshly, Pemuda Hijrah did not express accusations or criticisms of other Islamic groups. Based on research on his Instagram account, Pemuda Hijrah does not respond to criticism. It focuses more on collaborating with communities that are rarely in the circle of da'wah targets, such as hanging out, environmental, skateboarding, BMX, automotive, supporters, motorcycle gangs, and other communities.

Following sociological research conducted by Fajrani and Sugandi (2019), a study from social media shiftmedia.id shows that Islamic hijrah is a new social movement in millennial society that strengthens the identity of Muslims (Fajriani \& Sugandi, 2019). The identity shown from Pemuda Hijrah social media is symbolic through clothing symbols and in the hope of changing attitudes and more religious thoughts. The role of delivering studies, either within short videos or complete studies, also invites followers to participate in studies actively and deepen Islam. With social media, the Pemuda Hijrah participates in building spiritual revitalization through invitations wrapped in millennial style. The unique and creative ideas by Pemuda Hijrah manages in packaging various activities or campaigns can reference the da'wah movement directed at youth as da'wah's targets.

\section{Conclusion}

This study shows that Pemuda Hijrah (Shift) has strategic potential in influencing the millennial generation to revitalize spirituality through popular culture. The phenomenon of Pop Islamism in this study shows how Muslim youths use pop culture to promote the Islamic agenda by reinforcing religious values that are communicated creatively through social media in non-traditional, conventional, or formal ways. By deepening the packaged uniquely hijrah concept, it is hoped that the millennial generation yearning carries out positive activities and could improve and develop themselves to be more qualified people. Pemuda Hijrah Instagram account presents media functions through education, information sources, and creating differentiation. In addition to religious activities, Pemuda Hijrah also participates through social media campaigning on environmental issues, waste, reducing plastic use, planting trees, and the importance of sports. Interactions through Instagram with Social Media Marketing helped improve the branding of Pemuda Hijrah as an identity icon for the millennial Muslim generation in Indonesia. In addition to the Pemuda Hijrah study, there is an urgency to conduct other studies related to social media for da'wah's world from various scientific perspectives.

\section{References}

Abbas, S. (2020). The Rise Of Social Media In Indonesia | Incify - Digital Direct Response Agency.

Addini, A. (2019). Fenomena Gerakan Hijrah di Kalangan Pemuda Muslim Sebagai Mode Sosial. Journal of Islamic Civilization, 1(2), 109-118. https://doi. org/10.33086/jic.v1i2.1313

Affandi, N. R. D., \& Octavianti, M. (2019). Komunikasi Dakwah Pemuda Hijrah. Jurnal Manajemen Komunikasi, 3(2), 173. https://doi.org/10.24198/jmk. v3i2.20492

Anderson, S. (2019). Social Media Marketing 
for Business 2020: The Ultimate Guide to Boosting Your Business Through Social Media Marketing on Facebook, Instagram, Pinterest, And Twitter! In Independently Published.

Angela, N., \& Yoedtadi, M. G. (2019). Pemanfaatan Media Sosial Oleh Komunitas Historia Indonesia. Prologia, 3(2), 393. https://doi.org/10.24912/ pr.v3i2.6371

Arnus, S. H. (2018). Dakwah dan Kehidupan Beragama di Indonesia dalam Bingkai Media Sosial. In Religion Society dan Social Media (pp. 171-180). Sleman: Penerbit Deepublish.

Bakry, U. S. (2017). Pemanfaatan Metode Etnografi dan Netnografi Dalam Penelitian Hubungan Internasional. Jurnal Global \& Strategis, 11(1), 15. https://doi.org/10.20473/ jgs.11.1.2017.15-26

Dewantara, R. W., \& Widhyharto, D. S. (2016). Aktivisme dan Kesukarelawanan dalam Media Sosial Komunitas Kaum Muda Yogyakarta. Jurnal Ilmu Sosial Dan Ilmu Politik, 19(1), 40. https://doi. org/10.22146/jsp.10855

Dilawati, R., Darmawan, D., Hernawan, W., Waluyojati, R. R. S. R., \& Darmalaksana, W. (2020). Analisis Keberagamaan Pemuda Hijrah Komunitas Shift Perspektif Emik-etik. Jurnal Perspektif, 4(1), 54-65. https://doi.org/http:// dx.doi.org/10.15575/jp.v4i1.61

Fajriani, S. W., \& Sugandi, Y. S. (2019). Hijrah Islami Milenial Berdasarkan Paradigma Berorientasi Identitas. In Sosioglobal: Jurnal Pemikiran dan Penelitian Sosiologi (Vol. 3). https://doi.org/10.24198/JSG. V3I2.21643.G10733
Fatoni, U., \& Rais, A. N. (2018). Pengelolaan Kesan Da'i Dalam Kegiatan Dakwah di Pemuda Hijrah. KOMUNIKA: Jurnal Dakwah Dan Komunikasi, 12(2). https://doi.org/10.24090/komunika. v12i2.1342

Hasnawirda. (2012). Sejarah Ilmu Dakwah. Al-Munir, III(5).

Inkeles, A. (1964). What is Sociology?: An Introduction to the Discipline and Profession. Prentice-Hall.

Jayanto, D. D. (2020). Membaca Fenomena Menguatnya Perayaan "Islamisasi" di Indonesia Pasca Reformasi. Jurnal Kawistara, 10(1), 101. https://doi. org/10.22146/kawistara.42579

Jiang, S., \& Ngien, A. (2020). The Effects of Instagram Use, Social Comparison, and Self-Esteem on Social Anxiety: A Survey Study in Singapore. Social Media + Society, 6(2), 205630512091248. https://doi. org/10.1177/2056305120912488

Lianawati. (2011). Perbandingan Sosial.

Mulawarman, M., \& Nurfitri, A. D. (2017). Perilaku Pengguna Media Sosial beserta Implikasinya Ditinjau dari Perspektif Psikologi Sosial Terapan. Buletin Psikologi, 25(1), 36-44. https://doi. org/10.22146/buletinpsikologi.22759

Nizar, Y. A. (2020). Program less waste sebagai inovasi dakwah Hanan Attaki. Jurnal Ilmu Dakwah, 40(2), 115. https:// doi.org/10.21580/jid.v40.2.5762

Nurasiah Ismail, Abidin, Z., \& Fatoni, U. (2017). Pesan Dakwah tentang Nikah di Media Sosial Instagram. Tabligh: Jurnal Komunikasi Dan Penyiaran Islam, 2(1), 22-45. https://doi.org/https://doi. org/10.15575/tabligh.v2i1.30 
Pemuda Hijrah's Instagram Stats Summary Profile (Social Blade Instagram Statistics). (n.d.).

Pemuda Hijrah - HypeAuditor report for Instagram account shiftmedia. id | HypeAuditor Youtube, TikTok \& Instagram AI analytics. (2020).

pemudahijrah.id. (2020).

Prihatiningsih, W. (2017). Motif Penggunaan Media Sosial Instagram di Kalangan Remaja. Communication, 8(1), 51. https://doi.org/10.36080/comm. v8i1.651

Rofiqoh, I. (2019). Al-Azhar, Otoritas Keagamaan Baru dan Keislaman Indonesia: Peran Alumni Al-Azhar Mesir di Ruang Publik. UIN Sunan Kalijaga.

Slama, M., \& Barendregt, B. (2018). Introduction. Asiascape: Digital
Asia, 5(1-2), 3-31. https://doi. org/10.1163/22142312-12340090

Statistia. (2020). Instagram: users by country. Susanti. (2020, January). Sensus Penduduk 2020, Sensus Era Digital | Republika Online.

Turhamun, T. (2020). Strategi Komunikasi Fundraising Organisasi Kemasyarakatan. KOMUNIKA: Jurnal Dakwah Dan Komunikasi, 14(2), 199-212. https://doi. org/10.24090/komunika.v14i2.3783

Weng, H. W. (2015). Dakwah 2.0: Digital Dakwah, Street Dakwah and CyberUrban Activism among Chinese Muslims in Malaysia and Indonesia. In New Media Configurations and SocioCultural Dynamics in Asia and the Arab World (pp. 198-221). https://doi. org/10.5771/9783845253923-198 